\title{
IDENTIFIKASI PENGARUH PANDEMI COVID-19 TERHADAP PERILAKU PENGGUNA TWITTER DENGAN PENDEKATAN SOCIAL NETWORK ANALYSIS
}

\author{
Diana Purwitasari $^{* 1}$, Apriantoni², Agus Budi Raharjo ${ }^{3}$ \\ 1,2,3 Institut Teknologi Sepuluh Nopember, Surabaya \\ Email: 1diana.purwitasari@gmail.com, ${ }^{2}$ apriantoni.206025@mhs.its.ac.id,,agus.budi@its.ac.id \\ *Penulis Korespondensi
}

(Naskah masuk: 19 Oktober 2021, diterima untuk diterbitkan: 17 November 2021)

\begin{abstract}
Abstrak
Pandemi COVID-19 yang berlangsung lama telah berdampak masif pada berbagai aktivitas publik, misalnya perilaku pengguna di media sosial. Twitter, media sosial yang fleksibel untuk berdiskusi dan bertukar pendapat, menjadi salah satu media populer dalam menyebarluaskan informasi COVID-19 secara dinamis dan up-to-date. Hal ini menjadikan twitter relevan sebagai media ekstraksi pengetahuan dalam mengidentifikasi perubahan perilaku pengguna. Kontribusi penelitian ini adalah menemukan perubahan perilaku pengguna twitter melalui analisis profil pengguna pada periode sebelum dan setelah COVID-19. Data yang digunakan adalah data tweet berbahasa Indonesia. Penelitian ini menggunakan pendekatan Social Network Analysis (SNA) sebagai ekstraksi informasi dalam menentukan aktor utama dan aktor populer. Kemudian, profil pengguna aktif dianalisis untuk mengidentifikasi perubahan perilaku melalui intensitas tweet, popularitas pengguna, dan representasi topik pembahasan. Popularitas pengguna dianalisis dengan pendekatan follower rank, sedangkan representasi topik pembahasan diekstraksi dengan metode Latent Dirichlet Allocation untuk mendapatkan dominan topik yang dibahas oleh setiap pengguna aktif. Tujuannya adalah untuk mempermudah identifikasi pengaruh pandemi COVID-19 terhadap perubahan perilaku pengguna twitter. Berdasarkan hasil SNA, penelitian ini menemukan tiga aktor kunci yang aktif pada periode sebelum dan setelah COVID-19. Selanjutnya, hasil analisis dari ketiga aktor tersebut menunjukkan adanya pengaruh pandemi COVID-19 terhadap perubahan perilaku pengguna twitter, yaitu kenaikan intensitas tweet sebesar $58 \%$ pada jam kerja, aktor utama yang didominasi oleh $60 \%$ pengguna dengan follower rendah, dan topik pembicaraan pengguna twitter yang dominan membahas COVID-19, hobi dan aktivitas di dalam rumah.
\end{abstract}

Kata kunci: COVID-19, Social Network Analysis, Pemodelan Topik, Perilaku Pengguna, Profil Pengguna

\section{IDENTIFYING OF COVID-19 PANDEMIC EFFECT TOWARDS TWITTER USER BEHAVIOR WITH A SOCIAL NETWORK ANALYSIS APPROACH}

\begin{abstract}
The long-lasting COVID-19 pandemic had a massive impact on public activities, such as user behavior on social media. Twitter, a flexible social media for discussing and exchanging opinions, has become popular in disseminating COVID-19 dynamic and up-to-date information. It makes twitter relevant as a medium of knowledge extraction in identifying user behavior changes. The contribution of this research is to find behavior changes of Twitter users through user profiles analysis in the before and after COVID-19 period. This data used is Indonesian-language tweets. This research used a Social Network Analysis (SNA) to determine the main actors and famous actors. Then, active user profiles were analyzed to identify behavior changes through tweet intensity, user popularity, and representation of the topic of discussion. User popularity was analyzed using a follower rank approach. At the same time, the representation of discussion topics was extracted using the Latent Dirichlet Allocation method to obtain dominant topics which each active user discusses. It aims to make it easier to identify the impact of the COVID-19 pandemic on Twitter user behavior changes. Based on the results of the SNA, this research found three key actors who were active in the before and after COVID-19 period. Then, the results of the analysis of these three user profiles shows that an influence of the COVID-19 pandemic on Twitter user behavior changes: an increase in tweet intensity by 58\% during working hours, the leading actor was dominated by $60 \%$ of users with low followers, and the topic of Twitter users' conversation that it dominantly discuss COVID-19 issues, hobbies, and activities at home.
\end{abstract}

Keywords: COVID-19, Social Network Analysis, Topic Modeling, User Behaviour, User Profile 


\section{PENDAHULUAN}

CoronaVirus Disease-2019 (COVID-19) telah berdampak masif pada berbagai aktivitas publik, misalnya perilaku pengguna di sosial media (M. S. Ahmed et al., 2021). Pada awal pandemi COVID-19, jumlah pengguna sosial media meningkat dan twitter menjadi salah satu media populer dalam penyebaran informasi krisis tersebut (Valdez et al., 2020). Situasi krisis ini telah berlangsung lama sehingga dapat mempengaruhi perubahan perilaku pengguna twitter. Meningkatnya sentimen negatif (M. S. Ahmed et al., 2021) dan maraknya kekhawatiran resiko kesehatan (Basiri et al., 2021) adalah bagian dari perubahan perilaku. Kondisi ini menyebar dengan cepat dikalangan pengguna twitter melalui diskusi dan pertukaran konten informasi (Abd-Alrazaq et al., 2020). Konten yang dibagikan dapat mempengaruhi respon publik, selanjutnya berpotensi merubah perilaku karena adanya kesamaan persepsi. Perilaku positif bisa memberikan pengaruh yang baik, namun perubahan perilaku negatif dapat meningkatkan dampak negatif pandemi COVID-19 secara masif. Hal ini menunjukkan perlunya analisis perilaku pengguna twitter untuk mengidentifikasi perubahan perilaku akibat pengaruh pandemi COVID-19.

Penelitian terdahulu mengidentifikasi perilaku pengguna twitter menggunakan Social Network Analysis (SNA) untuk mengeksplorasi penyebaran sumber informasi dan mendeteksi pengguna berpengaruh dalam kelompok jaringan (Al-Shargabi \& Selmi, 2021). Penelitian berikutnya menggunakan pendekatan SNA untuk mengidentifikasi pengaruh ajakan memakai masker selama pandemi COVID-19 dikalangan pengguna twitter (Ahmed et al., 2020). Keduanya hanya berfokus pada analisis pengguna berpengaruh (influencer) dalam kelompok jaringan. Kemudian, data yang digunakan hanya periode COVID-19 sehingga ekstraksi perilaku yang didapatkan terbatas pada penyebaran informasi oleh aktor berpengaruh pada periode tersebut. Secara keseluruhan, keduanya menunjukkan bahwa SNA dapat digunakan sebagai ekstraksi pengaruh pengguna beradasarkan pertukaran informasi selama pandemi COVID-19.

Penelitian lain menggunakan Machine Learning (ML) untuk karakterisasi topik pembahasan data tweet terkait COVID-19. Selain itu, penelitian ini juga menggunakan pendekatan SNA untuk identifikasi penyebaran informasi disetiap kelompok jaringan pengguna (Haupt et al., 2021). Hal yang sama dilakukan pada identifikasi perubahan sikap dan pembahasan pengguna twitter berdasarkan analisis sentimen. Tetapi, pendekatan SNA pada penelitian ini hanya digunakan sebagai visualisasi alur informasi dari setiap pembahasan pengguna twitter (Hung et al., 2020). Penelitian lain membahas perilaku pengguna selama pandemi COVID-19 berdasarkan analisis sentimen. Berbeda dengan sebelumnya, penelitian ini mengidentifikasi pengguna aktif berdasarkan nilai keterlibatannya dalam jaringan (M. S. Ahmed et al., 2021). Ketiganya hanya berfokus pada analisis perilaku sentimen dan identifikasi alur informasi dari topik pembahasan terkait COVID-19. Namun, ketiganya menunjukkan bahwa pendekatan ML dapat membantu ekstraksi perilaku pengguna twitter secara kontekstual dengan baik.

Oleh karena itu, penelitian ini mengusulkan identifikasi perubahan perilaku pengguna twitter menggunakan SNA pada periode sebelum dan setelah COVID-19 menggunakan SNA. SNA merupakan pendekatan pada jaringan komunikasi untuk mengetahui bagaimana pengguna berhubungan satu sama lain melalui perilaku interaksi dan pertukaran informasi (Haupt et al., 2021). Selanjutnya, penelitian ini membagi data menjadi dua periode, yaitu sebelum dan setelah COVID-19, untuk mempermudah pemetaan perubahan perilaku pengguna twitter secara gradual. Selain itu, penelitian ini juga menggunakan pendekatan ML dalam proses ekstraksi perilaku untuk mendapatkan representasi topik pembahasan dari pengguna aktif twitter.

Penelitian ini bertujuan mengidentifikasi pengaruh pandemi COVID-19 terhadap perubahan perilaku pengguna twitter. Dalam penelitian ini, SNA digunakan untuk memetakan interaksi pengguna twitter yang terdesentralisasi dan terfragmentasi menjadi lebih sederhana (Pascual-Ferrá, Alperstein, \& Barnett, 2020), sehingga mempermudah proses ekstraksi pengetahuan dalam menentukan aktor utama (Tomasoa, Iriani, \& Sembiring, 2019) dan aktor populer (Mailoa, 2020). Selanjutnya, profil aktor tersebut dianalisis untuk mengidentifikasi perubahan perilaku pengguna melalui intensitas tweet, popularitas pengguna, dan representasi topik pembahasan. Popularitas pengguna dianalisis dengan pendekatan follower rank, sedangkan representasi topik pembahasan diekstraksi dengan metode Latent Dirichlet Allocation (LDA) untuk mendapatkan dominan topik yang dibahas oleh setiap pengguna aktif. Dari serangkaian proses tersebut, penelitian ini berkontribusi dalam melakukan analisis profil pengguna pada tweet berbahasa indonesia untuk mengidentifikasi perubahan perilaku pada periode sebelum dan setelah COVID-19.

Garis besar penelitian ini disusun dalam empat bagian. Bagian 1 berisi latar belakang permasalahan dan pentingnya menemukan solusi yang sesuai. Bagian 2 menjelaskan metode penelitian yang dilakukan beserta landasan teoritis yang relevan. Bagian 3 menyajikan hasil implementasi dan analisis penelitian. Terakhir, bagian 4 menguraikan kesimpulan dan peluang penelitian selanjutnya.

\section{METODE PENELITIAN}

Penelitian ini berfokus pada identifikasi pengaruh COVID-19 terhadap perubahan perilaku pengguna twitter. Identifikasi dilakukan melalui empat tahapan sesuai Gambar 1. 


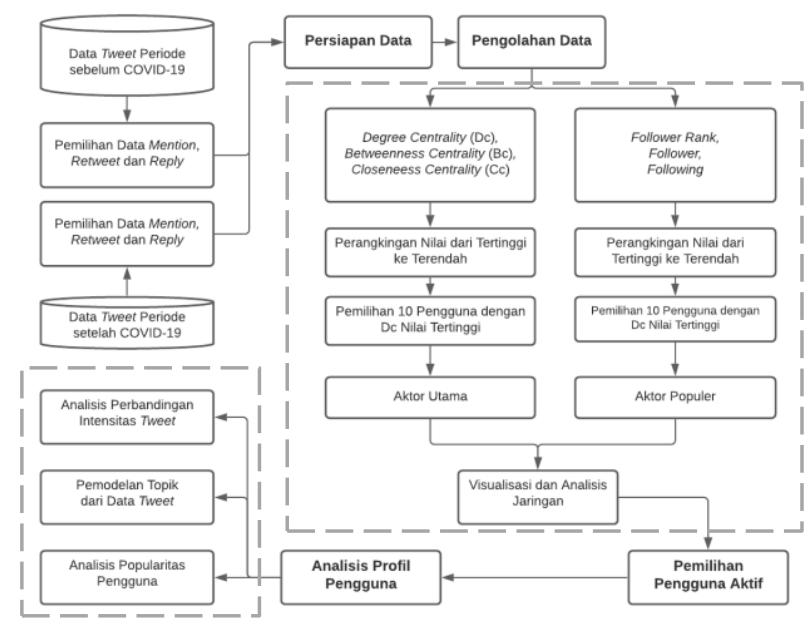

Gambar 1. Tahapan pada Identifikasi Pengaruh COVID-19 terhadap Perilaku Pengguna Twitter

\subsection{Persiapan Data}

Dataset diekstraksi dari Twitter menggunakan API Twitter, yang dikombinasikan dengan Twint library untuk mendapatkan intensitas tweet yang besar dengan cepat. Data yang didapatkan berupa tweet, retweet, mention, reply dan informasi statistik akun. Teknis pengambilan data didasarkan pada suatu titik lokasi dengan batasan radius $10 \mathrm{~km}$ (Zhao et al., 2020). Mekanisme ini bertujuan memperoleh intensitas tweet yang tinggi dilokasi yang strategis.

Proses pengambilan pada penelitian ini data dibagi ke dalam dua bagian, yaitu periode sebelum dan setelah COVID-19. Data periode sebelum COVID-19 berisi tweet selama 13 Desember 2019-13 Maret 2020, sedangkan periode setelah COVID-19 berisi tweet selama 14 Maret 2020-13 Juni 2020. Pembagian data ini bertujuan memetakan perbedaan perilaku pengguna twitter pada periode sebelum dan setelah COVID-19 (Valdez et al., 2020).

\subsection{Pengolahan Data}

Ekstraksi pengetahuan didasarkan pada dua cara, yaitu pencarian aktor utama dan aktor populer. Pada pencarian aktor utama, pendekatan pertama yang dilakukan adalah penentuan Degree Centrality (DC). DC merupakan rasio jumlah interaksi yang dimiliki sebuah node dengan node lain. Proses penentuan DC didapatkan dengan persamaan (1).

$D_{C}\left(N_{k}\right)=\sum_{i} x i j=\sum_{j} x j i$

Pada persamaan (1), nilai $D_{C}\left(N_{k}\right)$ didapatkan dari jumlah nilai $x_{i j}$ atau $x_{j i}$. Nilai $x_{i j}$ merepresentasikan banyaknya interaksi yang menghubungkan antara node $i$ dan $j$, sebaliknya, nilai $x_{j i}$ merepresentasikan banyaknya interaksi yang menghubungkan antara node $j$ dan node $i$. Jika antara node $i$ dan $j$ memiliki hubungan, maka interaksi keduanya dianggap 1. Node dengan jumlah $D_{C}\left(N_{k}\right)$ terbanyak menunjukkan bahwa node tersebut memiliki pengaruh yang tinggi pada jaringan (Yip \& To, 2021).
Pendekatan selanjutnya adalah Betweenness Centrality (BC) yang frekuensi node yang berperan sebagai penghubung antar jalur terpendek dari setiap jaringan. Proses penentuan BC didapatkan dengan persamaan (2).

$B_{c}\left(N_{k}\right)=\sum_{i, j \neq k} \frac{g_{i j k}}{g_{i j}}$

Pada persamaan (2), nilai $g_{i j k}$ merepresentasikan jumlah jalur dari node $j$ ke node $k$ yang melewati node $i$, sedangkan nilai $g_{i j}$ merepresentasikan jumlah jalur antara dua node dalam satu jaringan. Nilai $g_{i j k}$ kemudian dibagi dengan nilai $g_{i j}$ untuk mendapatkan nilai $B_{c}\left(N_{k}\right)$. Selanjutnya, $B_{c}\left(N_{k}\right)$ ini menunjukkan node atau aktor yang berperan sebagai perantara antar jalur terpendek dalam sebuah jaringan (Mittal et al., 2020).

Kemudian, pencarian dilanjutkan dengan Closeness Centrality (CC). CC merupakan perhitungan jarak rata-rata setiap node pada jaringan. Proses penentuan CC didapatkan dari persamaan (3).

$C_{c}\left(N_{k}\right)=\sum_{k=1}^{n} \frac{1}{d\left(N_{k}, N_{j}\right)}$

Berdasarkan persamaan (3), nilai $d\left(N_{k}, N_{j}\right)$ merepresentasikan jumlah jalur terpendek yang menghubungkan node $N_{k}$ dan $N_{j}$. Nilai $\operatorname{Cc}\left(N_{k}\right)$ didapatkan dengan membagi nilai 1 dengan nilai $d\left(N_{k}, N_{j}\right)$. Jika jarak terpendek node $N$ dengan node lain dalam satu jaringan bernilai kecil, maka node $N$ memiliki nilai CC yang sangat tinggi. Sebaliknya, jika jaraknya semakin jauh, maka node tersebut memiliki hubungan yang lemah dengan node lainnya (Mittal et al., 2020).

Berikutnya, proses perankingan data dilakukan dari hasil perhitungan nilai $\mathrm{DC}, \mathrm{BC}$ dan $\mathrm{CC}$. Node atau aktor dengan nilai DC tertinggi menunjukkan bahwa node tersebut memiliki pengaruh yang kuat pada sebuah jaringan. Node dengan nilai BC tertinggi menunjukkan bahwa node tersebut memiliki peran penting sebagai perantara antar jalur terpendek lainnya dalam sebuah jaringan. Kemudian, node dengan nilai Cc tertinggi menunjukkan bahwa node tersebut memiliki hubungan yang kuat dengan node induknya. Perankingan ini menghasilkan daftar pengguna aktif yang memiliki pengaruh kuat terhadap pengguna lain pada kelompok interaksinya.

Tahap pemrosesan selanjutnya adalah pencarian aktor populer. Penentuan aktor populer dapat dilakukan dengan pendekatan follower rank. Follower rank digunakan untuk mengetahui nilai popularitas dari node yang berpengaruh pada sebuah jaringan. Proses penentuan follower rank didapatkan dengan persamaan 4 .

Follower Rank $(i)=\frac{F 1}{F 1+F 3}$

Berdasarkan persamaan 4, F1 merepresentasikan banyaknya follower atau pengikut suatu aktor. Nilai F3 merepresentasikan banyaknya sebuah node yang 
Tabel 1. Perbandingan Data pada Periode Sebelum dan Setelah COVID-19

\begin{tabular}{llccc}
\hline \multirow{2}{*}{ No. } & \multicolumn{1}{c}{ Periode } & \multicolumn{2}{c}{ Sebelum Reduksi Data Tweet } & \multicolumn{2}{c}{ Setelah Reduksi Data Tweet } \\
\cline { 3 - 5 } & & Jumlah Tweet & $\begin{array}{c}\text { Jumlah Pengguna } \\
\text { Aktif }\end{array}$ & $\begin{array}{c}\text { Jumlah Tweet } \\
\text { Jumlah Pengguna } \\
\text { Aktif }\end{array}$ \\
\hline 1. & $\begin{array}{l}\text { Sebelum COVID-19 } \\
\text { (13 Desember 2019-13 Maret 2021) }\end{array}$ & 1.420 .738 & 73.529 & 305.165 \\
\hline 2. & $\begin{array}{l}\text { Seteleh COVID-19 } \\
\text { (14 Maret 2020-13 Juni 2021) }\end{array}$ & 1.640 .916 & 60.232 & 467.470 \\
\hline
\end{tabular}

terhubung dengan node lain (node friends). Kemudian, nilai follower rank didapatkan melalui pembagian nilai $F 1$ dengan jumlah nilai $F 1$ dan $F 3$. Semakin tinggi nilai follower rank, maka semakin banyak pengikutnya atau semakin populer aktor tersebut, dan begitu pula sebaliknya (Mailoa, 2020).

Berikutnya, proses perankingan dilakukan dari hasil perhitungan nilai follower rank. Node atau aktor dengan nilai follower rank tertinggi menunjukkan bahwa node tersebut memiliki pengikut yang banyak dan populer. Sebaliknya, node atau aktor dengan nilai follower rank terkecil menunjukkan bahwa node tersebut memiliki pengikut yang sedikit dan kurang populer pada sebuah jaringan. Kemudian, data tweet divisualisasikan ke bentuk graf untuk memetakan interaksi antar pengguna dalam suatu jaringan (Yao et al., 2021). Selanjutnya, bentuk dan pola komunikasi jaringan dianalisis untuk mengetahui perubahan interaksi dari pengguna twitter pada periode sebelum dan setelah COVID-19.

\subsection{Pemilihan Pengguna Aktif}

Pengguna aktif dipilih berdasarkan dari hasil ekstraksi pengetahuan aktor utama dan aktro populer. Pengguna yang dipilih adalah pengguna yang aktif pada periode sebelum dan setelah COVID-19. Hal ini bertujuan untuk mendapatkan perbedaan pola perilaku pengguna aktif pada periode sebelum dan setelah COVID-19.

\subsection{Analisis Profil Pengguna}

Analisis profil pengguna didasarkan dengan dua pendekatan, yaitu tinjauan profil pengguna aktif dan pemodelan topik dari tweet pengguna aktif. Tinjuan profil twitter dilakukan dengan mengunjungi laman twitter pengguna, sedangkan pemodelan topik dilakukan melalui mekanisme pemrosesan teks dari setiap tweet pengguna. Pada proses pemodelan topik, kumpulan tweet dimodelkan dengan metode Latent Dirichlet Allocation (LDA). LDA merupakan metode pemodelan topik yang banyak digunakan karena memiliki performa yang baik dalam memetakan dokumen ke kumpulan topik atau klaster yang sejenis (Abd-Alrazaq et al., 2020). Kemudian, model dievaluasi menggunakan coherence score untuk memvalidasi performa model yang dikembangkan. Hasil dari pemodelan topik ini dijadikan sebagai representasi pembahasan tweet setiap pengguna.

Mekanisme analisis profil pengguna aktif dilakukan melalui skenario uji coba yang memiliki tiga fokus analisis, yaitu perbandingan intensitas tweet, pemodelan topik dari data tweet dan analisis popularitas pengguna aktif. Setiap hasil uji coba ini kemudian dianalisis untuk mengidentifikasi pengaruh pandemi COVID-19 terhadap perubahan perilaku pengguna twitter.

\section{HASIL DAN PEMBAHASAN}

\subsection{Persiapan Data}

Informasi data tweet yang sudah dikumpulkan dapat dilihat pada Tabel 1. Mekanisme pengambilan data ini didasarkan pendekatan lokasi geografis. Titik lokasi pengambilan data dilakukan di daerah Setiabudi, Kota Jakarta, dengan angka pembulatan nilai latitude -6.22 dan nilai longitude 106.83. Data yang diambil memiliki batasan radius $10 \mathrm{~km}$ dari titik lokasi tersebut. Mekanisme ini bertujuan untuk memperoleh intensitas tweet yang tinggi di lokasi yang strategis.

Besarnya intensitas data yang diperoleh menyulitkan proses analisis, sehingga dilakukan proses reduksi data dengan hanya memilih data tweet dari pengguna yang aktif pada kedua periode. Proses ini diawali dengan mengakumulasi jumlah tweet pada setiap pengguna. Selanjutnya, data tweet dieliminasi dengan batas nilai ambang minimal enam tweet perhari. Hasil proses reduksi data dapat dilihat pada Tabel 1. Proses ini menghasilkan 383 pengguna aktif pada periode sebelum COVID-19 dan 292 pengguna aktif pada periode saat COVID-19. Dari jumlah pengguna aktif kedua periode tersebut, terdapat 123 pengguna yang aktif bersamaan pada periode sebelum COVID-19 dan setelah COVID-19. Kemudian, hasil reduksi data tersebut dinormalisasi dengan mengakumulasi jumlah interaksi antar pengguna pada aktivitas mentions, retweet dan reply. Hasil normalisasi kemudian disimpan ke format matriks interaksi untuk mempermudah pemetaan aktivitas yang dilakukan setiap pengguna.

\subsection{Pengolahan Data}

Setiap interaksi tweet divisualisasikan ke bentuk graf menggunakan NeworkX (Abdelsadek et al., 2018). Berdasarkan hasil pada Tabel 1, 552 pengguna aktif direpresentasikan sebagai aktor atau node, sedangkan interaksi mentions, retweet dan reply antar pengguna direpresentasikan sebagai sebuah edges. Untuk mempermudah proses pengamatan, visualisasi jaringan periode sebelum COVID-19 menggunakan batas degree rank=3, sedangkan periode setelah COVID menggunaan batas degree rank $=60$. Bentuk graf keduanya ditunjukkan Gambar 2. Visualisasi tersebut menunjukkan bahwa graf periode sebelum 


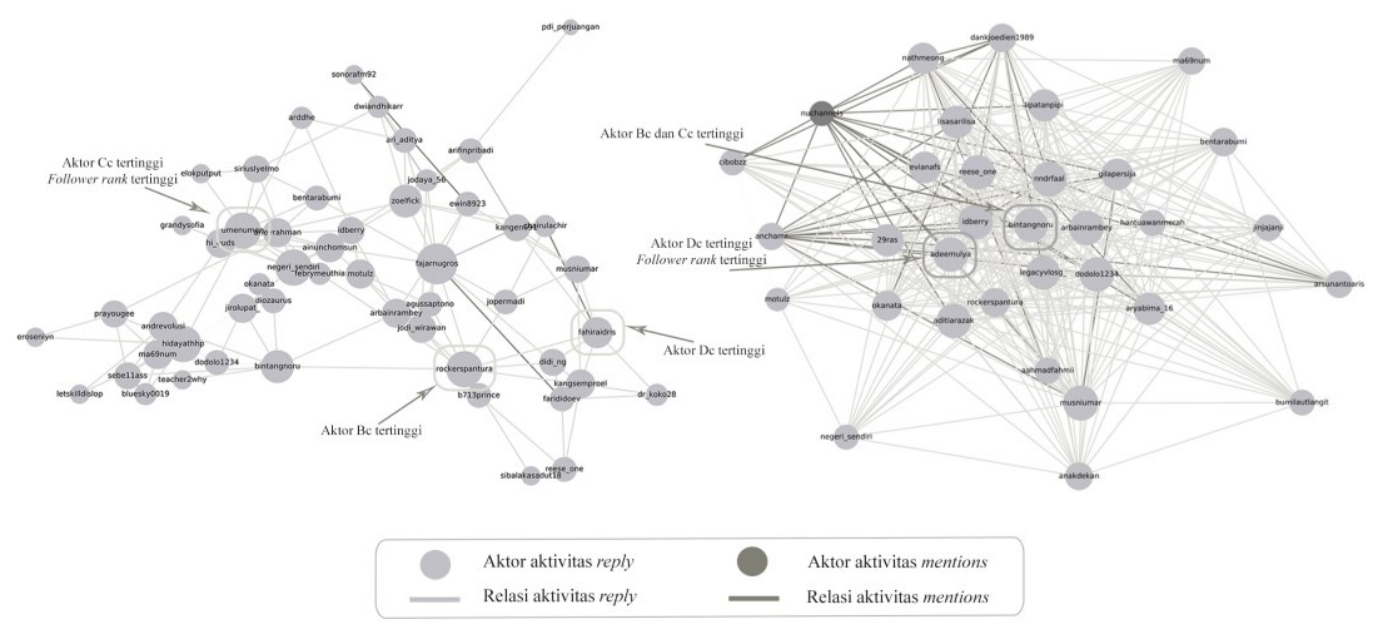

Gambar 2. Bentuk Graf Periode Sebelum COVID-19 (kiri) dan Periode Setelah COVID-19 (kanan)

COVID-19 didominasi oleh dua kelompok besar, yaitu satu kelompok dengan nilai popularitas tinggi dan satu kelompok lain dengan nilai popularitas rendah. Graf tersebut memiliki relasi desentralisasi sehingga alur informasi menyebar secara cepat di beberapa pusat yang berbeda. Sebaliknya, graf pada periode setelah COVID-19 hanya didominasi satu kelompok jaringan. Graf tersebut memiliki relasi jaringan membentuk pola clique graph dengan nilai densitas dan popularitas yang tinggi. Hal ini menyebabkan alur informasi jaringan tersentralisasi di satu pusat yang sama secara dependen.

Berdasarkan perbandingan interaksi, aktivitas reply mendominasi interaksi jaringan, sedangkan aktivitas mentions memiliki jumlah interaksi yang kecil. Aktivitas retweet tidak memiliki interaksi yang signifikan sehingga tidak terlihat dalam data graf yang sudah direduksi. Alur komunikasi retweet dan mentions juga tidak menunjukkan perubahan yang signifikan, tidak seperti aktivitas reply yang meningkat signifikan. Kemudian, bentuk kedua graf juga memiliki perbedaan intensitas postingan yang signifikan. Periode setelah COVID-19 memiliki kompleksitas postingan yang jauh lebih tinggi dibandingkan periode sebelum COVID-19.

Selanjutnya, jaringan dikelompokkan dengan pendekatan node community. Pengelompokan node ini didasarkan pada fragmentasi modularitas. Hasil pengelompokan itunjukkan pada Tabel 2. Nilai modularitas yang mendekati 1 menunjukkan pembagian yang jelas antar komunitas, sedangkan nilai kurang dari 0,5 menunjukkan bahwa komunitas lebih tumpang tindih dan jarak antar node lebih rapat (Pascual-Ferrá et al., 2020). Periode setelah COVID-

Tabel 2. Perbandingan Node Community

\begin{tabular}{llcc}
\hline No. & Overview & $\begin{array}{c}\text { Sebelum } \\
\text { COVID-19 }\end{array}$ & $\begin{array}{c}\text { Setelah } \\
\text { COVID-19 }\end{array}$ \\
\hline 1. & Average Degree & 3.24 & 35.06 \\
\hline 2. & Max. Network Degree & 17 & 202 \\
\hline 3 & Graph Density & 0.01 & 0.09 \\
\hline 4. & Modularity & 0.38 & 0.01 \\
\hline 5. & Class & 2 & 1 \\
\hline
\end{tabular}

19 mengalami kenaikan average degree yang signifikan. Kenaikan ini sejalan dengan meningkatnya intensitas tweet pada periode tersebut. Perubahan ini mempengaruhi sentralitas jaringan, semakin besar nilai average degree maka jaringan semakin besar dan kuat. Hal ini menyebabkan distribusi informasi lebih cepat di kelompok jaringan yang sama (Martin \& Niemeyer, 2020). Densitas graf periode setelah COVID-19 juga lebih tinggi dari periode sebelum COVID-19. Ini menunjukkan bahwa bentuk komunikasi jaringan periode setelah COVID19 adalah sentralisasi yang memiliki interaksi yang kuat dan kompleks sehingga mempermudah penyebaran informasi antar node dalam satu kelompok (Pascual-Ferrá et al., 2020).

Langkah selanjutnya adalah penentuan nilai DC, BC dan CC. Hasil perhitungan ketiganya dapat dilihat pada Tabel 3. Dari hasil perhitungan ini, terdapat tiga akun yang aktif di periode sebelum dan setelah COVID-19. Ketiganya memiliki kenaikan DC yang signifikan pada periode setelah COVID-19. Ini menunjukkan interaksi pada periode setelah COVID19 jauh lebih banyak daripada periode sebelum COVID-19. Selanjutnya, ketiganya memiliki penurunan nilai BC pada periode setelah COVID-19. Bentuk jaringan dengan satu node community menyebabkan terjadinya sentralisasi informasi sehingga mengurangi node yang berperan sebagai aktor BC pada jaringan ini. Kemudian ketiganya juga mengalami kenaikan nilai CC pada periode setelah COVID-19. Dekomposisi sub-jaringan yang sedikit menyebabkan interaksi antar node tidak banyak sehingga node yang berperan sebagai aktor CC juga berkurang namun derajat hubungan antar node menjadi semakin kuat. Hal ini menyebabkan jarak antara ketiganya dengan node lain lebih dekat pada periode setelah COVID-19 karena dipengaruhi bentuk jaringan yang berpola clique graph.

Tabel 3 juga menunjukkan tujuh akun yang aktif dari periode sebelum COVID-19 tetapi yang tidak aktif di periode setelah COVID-19. Dari hasil analisis DC, BC dan CC, ketujuh akun tersebut masuk dalam 
Tabel 3. Pengguna Aktif Periode Sebelum dan Setelah COVID-19

\begin{tabular}{|c|c|c|c|c|c|c|c|c|}
\hline \multirow[b]{2}{*}{ No. } & \multicolumn{4}{|c|}{ Periode Sebelum COVID-19 } & \multicolumn{4}{|c|}{ Periode Setelah COVID-19 } \\
\hline & Aktor & $\begin{array}{c}\text { Degree } \\
\text { Centrality }\end{array}$ & $\begin{array}{c}\text { Betweenness } \\
\text { Centrality }\end{array}$ & $\begin{array}{l}\text { Closeness } \\
\text { Centrality }\end{array}$ & Aktor & $\begin{array}{c}\text { Degree } \\
\text { Centrality }\end{array}$ & $\begin{array}{c}\text { Betweenness } \\
\text { Centrality }\end{array}$ & $\begin{array}{l}\text { Closeness } \\
\text { Centrality }\end{array}$ \\
\hline 1. & @fahiraidris & 19 & 0.08 & 0.22 & @adeemulya & 202 & 0.04 & 0.63 \\
\hline 2. & @)hidayathhp & 18 & 0.10 & 0.23 & @bintangnoru & 201 & 0.05 & 0.64 \\
\hline 3. & @)fajarnugros & 16 & 0.07 & 0.22 & @nndrfaal & 185 & 0.04 & 0.61 \\
\hline 4. & @rockerspantura & 14 & 0.15 & 0.24 & @arbainrambey & 184 & 0.03 & 0.61 \\
\hline 5. & (a)zoelfick & 14 & 0.10 & 0.23 & @evianafs & 176 & 0.02 & 0.59 \\
\hline 6. & (a)umenumen & 14 & 0.12 & 0.25 & @rockerspantura & 175 & 0.03 & 0.58 \\
\hline 7. & (a)negeri_sendiri & 12 & 0.06 & 0.24 & @hantuawanmerah & 170 & 0.03 & 0.58 \\
\hline 8. & @musniumar & 12 & 0.02 & 0.20 & @okanata & 164 & 0.03 & 0.57 \\
\hline 9. & @arievrahman & 11 & 0.06 & 0.23 & @aryabima_16 & 162 & 0.02 & 0.58 \\
\hline 10. & (a)bintangnoru & 10 & 0.14 & 0.24 & @musniumar & 159 & 0.05 & 0.59 \\
\hline
\end{tabular}

dalam 50 besar pengguna aktif periode setelah COVID-19, namun tidak lagi berperan sebagai aktor utama pada jaringan. Kemudian juga terdapat tujuh akun yang tidak aktif pada periode sebelum COVID19 tetapi menjadi pengguna aktif di periode setelah COVID-19. Dari hasil analisis DC, BC dan CC, ketujuh akun tersebut masuk dalam dalam 100 besar pengguna aktif periode sebelum COVID-19, namun tidak berperan sebagai aktor utama pada jaringan.

Selanjutnya, analisis ego network dilakukan untuk menelusuri keterkaitan antar node berdasarkan node friends dan social-structure yang tidak terlihat dalam jaringan utuh. Hal ini dapat memberikan informasi pengaruh node dalam lingkaran interaksi disekitarnya (Stolz \& Schlereth, 2021). Penelusuran node dilakukan dengan nilai network radius 3 . Hasil penelurusan ego network ditampilkan Tabel 4. Node friends merepresentasikan node lain yang terhubung secara bertingkat, sedangkan clustering coefficient merupakan proporsi node friends yang juga berteman satu sama lain.

Tabel 4 menunjukkan dominan pengguna mengalami kenaikan DC yang ditandai dengan meningkatnya nilai node friends. Hal ini menunjukkan kelompok jaringan disekitar mereka membahas penyebaran topik yang mereka ikuti secara stabil. Menariknya, keseluruhan node memiliki kenaikan clustering coefficient di sekitaran 0.31-0.32. Hal ini menunjukkan node disekitar mereka aktif melakukan aktivitas retweet dari pembahasan yang mereka buat dengan skor proporsi yang relatif sama. Berdasarkan derajat clustering coefficient, kenaikan tertinggi dimiliki oleh akun @adeemulya,@nndrfaal dan@hantuawanmerah. Pada periode sebelum COVID-19, ketiganya memiliki nilai clustering coefficient 0 , namun periode setelah COVID-19 mengalami kenaikan nilai clustering coefficient sebesar 0.31. Hal ini menunjukkan ketiganya membuat pembahasan tweet yang mempengaruhi aktivitas pengguna disekitarnya. Pembahasan ini menyebabkan interaksi menjadi intens sehingga menaikkan DC ketiga pengguna tersebut. Sebaliknya, dominan pengguna aktif periode sebelum COVID-19 mengalami kenaikan clustering coefficient yang tidak signifikan pada periode setelah COVID-19. Nilai ini lebih kecil dibanding pengguna aktif lain pada periode setelah COVID-19. Hal ini menyebabkan pengguna aktif periode sebelum COVID-19 dominan mengalami penurunan pengaruhya dalam jaringan komunitasnya sehingga mereka tidak lagi menjadi aktor utama jaringan pada periode setelah COVID-19.

Selanjutnya melakukan analisis profil twitter dari 14 akun pada Tabel 4. Proses ini dilakukan untuk mengidentifikasi perubahan perilaku yang terjadi pada pengguna yang tidak aktif dikedua periode. Analisis profil dilakukan dengan dua pendekatan, yaitu tinjauan profil twitter dan pemodelan topik dari tweet pengguna. Hasil analisis tersebut ditampilkan pada Tabel 5. Dari hasil analisis profil tersebut, intensitas dan pembahasan tweet pengguna aktif periode sebelum dan setelah COVID-19 mengalami

Tabel 4. Perbandingan Ego Network Pengguna Aktif Periode Sebelum dan Setelah COVID-19

\begin{tabular}{|c|c|c|c|c|c|c|}
\hline \multirow[t]{2}{*}{ No. } & \multirow{2}{*}{ Aktor } & \multirow{2}{*}{ Follower } & \multicolumn{2}{|c|}{ Periode Sebelum COVID-19 } & \multicolumn{2}{|c|}{ Periode Setelah COVID-19 } \\
\hline & & & Node Friends & Average Coefficient & Node Friends & Average Coefficient \\
\hline 1. & (a)fahiraidris & 608.775 & 90 & 0.27 & 354 & 0.31 \\
\hline 2. & @)hidayathhp & 7.991 & 93 & 0.20 & 354 & 0.32 \\
\hline 3. & @)fajarnugros & 85.878 & 110 & 0.18 & 355 & 0.31 \\
\hline 4. & (a)zoelfick & 58.241 & 116 & 0.22 & 352 & 0.32 \\
\hline 5. & @umenumen & 11.832 & 116 & 0.20 & 353 & 0.32 \\
\hline 6. & (a)negeri_sendiri & 9.705 & 111 & 0.20 & 356 & 0.32 \\
\hline 7. & (a)arievrahman & 51.162 & 112 & 0.21 & 350 & 0.33 \\
\hline 8. & @adeemulya & 986 & 2 & 0 & 364 & 0.31 \\
\hline 9. & (a)nndrfaal & 1.681 & 0 & 0 & 363 & 0.31 \\
\hline 10 & @arbainrambey & 131.264 & 95 & 0.24 & 363 & 0.31 \\
\hline 11. & (a)vianafs & 4.006 & 34 & 0.23 & 358 & 0.32 \\
\hline 12. & @hantuawanmerah & 1.981 & 0 & 0 & 357 & 0.31 \\
\hline 13. & @okanata & 1.827 & 68 & 0.28 & 357 & 0.32 \\
\hline 14. & (a) aryabima 16 & 325 & 11 & 0.40 & 359 & 0.31 \\
\hline
\end{tabular}


Tabel 5. Pembahasan Pengguna Aktif pada Periode sebelum dan Setelah COVID-19

\begin{tabular}{|c|c|c|c|c|}
\hline No. & Aktor & Profesi & Pembahasan sebelum COVID-19 & Pembahasan setelah COVID-19 \\
\hline 1. & @)fahiraidris & $\begin{array}{l}\text { Anggota } \\
\text { MPR RI }\end{array}$ & $\begin{array}{l}\text { Banjir, pekerjaan, sidang, politik dan } \\
\text { pemerintahan, banduan dan donasi, ibadah, } \\
\text { himbauan dan motivasi dan aktivitas pribadi }\end{array}$ & $\begin{array}{l}\text { COVID-19, himbauan kesehatan, bantuan bencana, } \\
\text { pekerjaan, pemerintah dan politik, donasi, keluarga } \\
\text { dan aktivitas pribadi dan ibadah }\end{array}$ \\
\hline 2. & @hidayathhp & $\begin{array}{l}\text { Staff Anggota } \\
\text { DPRD }\end{array}$ & $\begin{array}{l}\text { Hobi, politik dan pemerintahan, pekerjaan dan } \\
\text { kepedulian masyarakat }\end{array}$ & $\begin{array}{l}\text { COVID-19, pekerjaan, politik dan pemerintahan, } \\
\text { aktivitas pribadi, motivasi hidup dan ibadah }\end{array}$ \\
\hline 3. & @fajarnugros & Direktur Film & $\begin{array}{l}\text { Film, bioskop, politik dan pemerintahan, } \\
\text { fenomena sosial, kunjungan daerah dan UMKM }\end{array}$ & $\begin{array}{l}\text { COVID-19, seni dan film, UMKM, aktivitas } \\
\text { pribadi, motivasi, kebijakan pemerintah dan hobi }\end{array}$ \\
\hline 4. & @zoelfick & Jurnalis & $\begin{array}{l}\text { Keluarga, fenomena sosial, kuliner, politik dan } \\
\text { pemerintahan, pekerjaan, jurnalistik dan film. }\end{array}$ & $\begin{array}{l}\text { COVID-19, aktivitas pribadi, keluarga, kebijakan } \\
\text { pemerintah, pekerjaan dan hobi }\end{array}$ \\
\hline 5. & (a) umenumen & Entrepreneur & $\begin{array}{l}\text { Pekerjaan, transaksi penjualan atau pembelian, } \\
\text { olahraga, rapat kerja, dan aktivitas pribadi }\end{array}$ & $\begin{array}{l}\text { COVID-19, hobi, aktivitas pribadi, pekerjaan, } \\
\text { UMKM, ibadah dan online marketing }\end{array}$ \\
\hline 6. & (@)negeri_sendiri & Akun Blogger & $\begin{array}{l}\text { Lokasi wisata, hobi dan olahraga, informasi } \\
\text { publik dan kuliner }\end{array}$ & $\begin{array}{l}\text { Lokasi wisata, COVID-19, himbauan kesehatan, } \\
\text { hobi dan olahraga, UMKM dan kuliner }\end{array}$ \\
\hline 7. & @arievrahman & Traveller & $\begin{array}{l}\text { Travelling, kuliner, film dan video, transportasi, } \\
\text { lokasi wisata, hobi dan aktivitas pribadi. }\end{array}$ & $\begin{array}{l}\text { Hobi, ibadah, COVID-19, olahraga, keluarga, } \\
\text { aktivitas pribadi dan informasi travelling }\end{array}$ \\
\hline 8. & (a)adeemulya & Mahasiswa & $\begin{array}{l}\text { Kuliah, tugas, olahraga, hobi, aktivitas pribadi, } \\
\text { politik dan pemerintahan }\end{array}$ & $\begin{array}{l}\text { COVID-19, ibadah, hobi, olahraga, politik dan } \\
\text { pemerintahan, belajar online, aktivitas pribadi }\end{array}$ \\
\hline 10. & @arbainrambey & Jurnalis & $\begin{array}{l}\text { Pekerjaan, media dan iklan, politik dan } \\
\text { pemerintahan, fotografi, videografi dan hobi }\end{array}$ & $\begin{array}{l}\text { Jurnalistik, COVID-19, politik dan pemerintahan, } \\
\text { keluarga, fotografi, artikel dan tulisan online }\end{array}$ \\
\hline 11. & @evianafs & $\begin{array}{l}\text { Driver Ojek } \\
\text { Online }\end{array}$ & $\begin{array}{l}\text { Pekerjaan, keluarga, aktivitas pribadi, anak- } \\
\text { anak dan berbelanja }\end{array}$ & $\begin{array}{l}\text { Work From Home, aktivitas pribadi, keluarga, } \\
\text { belanja dan anak sekolah }\end{array}$ \\
\hline 12. & @hantuawanmerah & Karyawan & Pekerjaan, hobi, olahraga, dan aktivitas pribadi & $\begin{array}{l}\text { Work From Home, ibadah, politik dan } \\
\text { pemerintahan, aktivitas pribadi dan hobi }\end{array}$ \\
\hline 13. & @okanata & Entrepreneur & $\begin{array}{l}\text { Promosi produk, hobi, olahraga, politik dan } \\
\text { pemerintahan, aktivitas pribadi dan kuliner }\end{array}$ & $\begin{array}{l}\text { Kuliner, COVID-19, resep makanan, ibadah, hobi, } \\
\text { olahraga, aktivitas pribadi dan promosi online }\end{array}$ \\
\hline 14 & @aryabima_16 & Karyawan & Aktivitas pribadi, pekerjaan dan hobi & $\begin{array}{l}\text { Work From Home, ibadah, hobi dan aktivitas } \\
\text { pribadi }\end{array}$ \\
\hline
\end{tabular}

perubahan. Misalnya, akun @fahiraidris dan @ hidayathhp yang berprofesi sebagai pejabat pemerintahan. Selama masa COVID-19, pembahasan keduanya didominasi topik COVID-19, bantuan dan donasi serta himbauan kesehatan ke masyarakat. Keduanya juga banyak membahas aktivitas kerja di masa pandemi. Sepertinya pengaruh sebagai pejabat publik dalam membantu menangani permasalahan pandemi menyebabkan berkurangnya intensitas menggunakan sosial media twitter. Kemudian akun @fajarnugros,@zoelfick,@umenumen dan @arievrahman pada periode sebelum COVID-19 dominan melakukan aktivitas diluar rumah. Aktivitas ini berkaitan dengan profesi yang mereka jalani. Selama masa pandemi, keempatnya dominan melakukan aktivitas pekerjaan dan hobi, padahal sebelum pandemi tidak banyak beraktivitas terkait hobi. Kemudian akun@negeri_lama, akun yang bersifat bisnis, menyebarkan banyak informasi mengenai wisata dan informasi publik. Selama pandemi, akun ini juga menyebarkan informasi terkait COVID-19. Dengan adanya pandemi COVID19, hal-hal seperti ini bisa berpengaruh pada berkurangnya intensitas tweet yang mereka lakukan.

Berdasarkan Tabel 5, perubahan akun aktif periode setelah COVID-19 didominasi oleh pengguna yang melakukan work from home atau school from home. Misalnya, akun@adeemulya dan @nndrfaal yang membahas mengenai sekolah online, serta@aryabima_16,@ @hantuawanmera dan (a) evianafs yang membahas mengenai aktivitas work from home. Hal ini berkaitan dengan himbauan pemerintah untuk melakukan pekerjaan dari rumah agar menekan penyeberan virus COVID-19 secara masif. Kemudian akun@arbainrameydan@okanata yang banyak membahas aktivitas online seperti menulis artikel dan promosi online yang sesuai dengan profesi mereka. Aktivitas mereka berdua mengalami perubahan semenjak COVID-19 dari dominan aktivitas offline ke aktivitas online. Hal ini

Tabel 6. Perbandingan Follower Rank Pengguna Aktif Periode Sebelum dan Setelah COVID-19

\begin{tabular}{|c|c|c|c|c|c|c|c|c|}
\hline \multicolumn{5}{|c|}{ Periode Sebelum COVID-19 } & \multicolumn{4}{|c|}{ Periode Setelah COVID-19 } \\
\hline No. & Aktor & Follower & Following & $\begin{array}{c}\text { Follower } \\
\text { Rank }\end{array}$ & Aktor & Follower & Following & $\begin{array}{c}\text { Follower } \\
\text { Rank }\end{array}$ \\
\hline 1. & (a)fahiraidris & 608.775 & 27.95 & 0.96 & (a)adeemulya & 986 & 1.324 & 0.99 \\
\hline 3. & (a)fajarnugros & 85.878 & 2.696 & 0.97 & (a)nndrfaal & 1.681 & 3.204 & 0.34 \\
\hline 4. & (a)rockerspantura & 41.765 & 2.769 & 0.94 & @arbainrambey & 131.264 & 1.927 & 0.98 \\
\hline 5. & (a)zoelfick & 58.241 & 2.709 & 0.96 & (a) evianafs & 4.006 & 1.015 & 0.80 \\
\hline 7. & @negeri_sendiri & 9.705 & 1.408 & 0.87 & (a)hantuawanmerah & 1.981 & 1.841 & 0.52 \\
\hline 8. & @musniumar & 130.908 & 2.958 & 0.98 & (a)okanata & 1.827 & 892 & 0.01 \\
\hline 9. & @arievrahman & 51.162 & 1.521 & 0.97 & @aryabima_16 & 325 & 1.056 & 0.98 \\
\hline 10. & @bintangnoru & 18.167 & 1.785 & 0.91 & @)musniumar & 130.908 & 2.958 & 0.98 \\
\hline
\end{tabular}


menunjukkan bahwa aktivitas selama pandemi yang mengharuskan warga tetap dirumah saja dapat mempengaruhi perubahan perilaku pengguna twitter dalam menggunakan sosial media twitter.

\subsection{Pemilihan Pengguna Aktif}

Tabel 3 menunjukkan tiga pengguna twitter yang aktif pada kedua periode sebelum dan setelah COVID-19, yaitu@bintangnoru,@rockerspantura dan@musniumar. Ketiganya mengalami kenaikan nilai DC yang signifikan pada periode setelah COVID-19. Bahkan, akun@bintangnoru memiliki nilai DC paling tinggi diantara ketiganya dengan nilai DC sebesar 201. Nilai ini meningkat 20 kali dari periode sebelum COVID-19.

Proses selanjutnya adalah menghitung follower rank. Hasil perhitungan ini dapat dilihat pada Tabel 6. Berdasarkan hasil tersebut, ketiganya memiliki jumlah follower lebih dari 10k. Ini menunjukkan bahwa ketiganya merupakan tipe aktor populer dan berpengaruh dalam jaringan interaksinya. Jika dilihat berdasarkan nilai follower, cukup wajar jika ketiganya aktif pada periode sebelum dan setelah COVID-19. Dari ketiga pengguna tersebut, akun @ musniumar memiliki nilai follower rank tertinggi dengan nilai sebesar 0.98 dan memiliki nilai follower tertinggi dengan jumlah 130.098 follower.

\subsection{Analisis Profil Pengguna}

\section{A. Perbandingkan topik tweet pengguna aktif pada periode sebelum dan setelah COVID-19}

Pada penelitian ini, mekanisme pemrosesan teks diawali dengan menangani case folding. Proses selanjutnya adalah menghapus special character dalam teks, misalnya tautan, emoji, entitas HTML, mentions, tanda baca dan angka. Setelah itu, proses dilanjutkan dengan melakukan tokenisasi. Data tweet yang diolah berbahasa Indonesia, sehingga proses berikutnya adalah menghapus stopword berdasarkan referensi bahasa Indonesia. Proses ini dilakukan dengan dua cara, yaitu penghapusan tweet menggunakan referensi stopword dan penghapusan manual dengan menghilangkan kata-kata yang tidak terkait topik. Selanjutnya, proses normalisasi kata dilakukan untuk mengubah kata-kata slang menjadi kata baku sesuai preferensi bahasa Indonesia. Kemudian, proses berikutnya adalah stemming dan lemmatization untuk mengubah setiap kata menjadi bentuk dasar dan mengurangi bentuk infleksi dari morfologis kata-kata tersebut. Proses terakhir adalah penandaan part-of-speech (POS). Klausa yang dipilih dalam proses ini adalah nomina, adjektiva, verba, dan adverbia. Hasil dari serangkaian proses tersebut menghasilkan data teks bersih yang dapat digunakan untuk proses pemodelan topik.

Selanjutnya, data dimodelkan dengan metode LDA. Proses ini menghasilkan topik maksimum sebanyak 74 topik pada periode sebelum COVID-19 dengan coherence score sebesar 0.69 dan 25 topik pada periode setelah COVID-19 dengan coherence score sebesar 0.72. Hasil ini menunjukkan bahwa model LDA memiliki coherence score yang baik, namun jumlah maksimum topiknya cukup tinggi sehingga dapat mempersulit proses analisis. Oleh karena itu, proses hirarki topik dilakukan untuk mengklasterisasi topik yang memiliki kemiripan sehingga topik tersebut dapat digabungkan menjadi satu klaster yang sama. Proses ini dapat membantu mengurangi jumlah maksimum topik menjadi lebih kecil (Lossio-Ventura et al., 2021). Mekanisme ini menggunakan representasi TF-IDF untuk melakukan ekstraksi fitur teks dan cosine similarity untuk mengukur kemiripan hirarki teks dari masing-masing topik. Metode yang digunakan untuk klaterisasi topik adalah Agglomerative Clustering dan K-Means (Costa \& Ortale, 2021). Dari hasil pengelompokan topik tersebut, lima topik ditetapkan sebagai ambang batas topik utama. Hasilnya, metode Agglomerative Clustering menghasilkan nilai Silhouette Coefficient (SC) sebesar 0.81 untuk periode sebelum COVID-19 dan 0.62 untuk periode setelah COVID-19. Kemudian, K-Means memiliki nilai SC sebesar 0.64 untuk periode sebelum COVID-19 dan 0.61 untuk periode setelah COVID-19. Hasil ini menunjukkan bahwa klasterisasi hirarki topik dengan metode Aglomerative memiliki hasil yang lebih baik.

Tabel 7. Perbandingan Topik Tweet Pengguna Aktif pada periode sebelum dan Setelah COVID-19

\begin{tabular}{|c|c|c|c|c|c|c|}
\hline \multirow[b]{2}{*}{ No. } & \multicolumn{2}{|c|}{ abintangnoru } & \multicolumn{2}{|c|}{ @musniumar } & \multicolumn{2}{|c|}{ @rockerpantura } \\
\hline & $\begin{array}{l}\text { Sebelum } \\
\text { COVID-19 } \\
\end{array}$ & $\begin{array}{l}\text { Setelah } \\
\text { COVID-19 }\end{array}$ & $\begin{array}{l}\text { Sebelum } \\
\text { COVID-19 } \\
\end{array}$ & $\begin{array}{l}\text { Setelah } \\
\text { Covid-19 }\end{array}$ & $\begin{array}{l}\text { Sebelum } \\
\text { COVID-19 } \\
\end{array}$ & $\begin{array}{l}\text { Setelah } \\
\text { COVID-19 }\end{array}$ \\
\hline 1. & $\begin{array}{l}\text { pulang makan es } \\
\text { sency pim } \\
\text { (Makanan) }\end{array}$ & $\begin{array}{l}\text { rumah biaya sehat } \\
\text { gila masker } \\
\text { (COVID-19) }\end{array}$ & $\begin{array}{l}\text { kampus macet } \\
\text { pulang anak daerah } \\
\text { (pekerjaan) }\end{array}$ & $\begin{array}{l}\text { universitas jakarta } \\
\text { civitas akademika doa } \\
\text { (pendidikan) }\end{array}$ & $\begin{array}{l}\text { rumah berita gempa } \\
\text { kopi beli } \\
\text { (aktivitas pribadi) }\end{array}$ & $\begin{array}{l}\text { masker rumah jaga } \\
\text { RS medis } \\
\text { (COVID-19) }\end{array}$ \\
\hline 2. & $\begin{array}{l}\text { kantor jalan pulang } \\
\text { malam banjir } \\
\text { (pekerjaan) }\end{array}$ & $\begin{array}{l}\text { bosan kamar lupa } \\
\text { teman online } \\
\text { (lockdown) }\end{array}$ & $\begin{array}{l}\text { makan mudik ayah } \\
\text { lokasi handphone } \\
\text { (aktivitas pribadi) }\end{array}$ & $\begin{array}{l}\text { covid ekonomi dunia } \\
\text { pemerintah phk } \\
\text { (COVID-19) }\end{array}$ & $\begin{array}{l}\text { balap takut malam } \\
\text { salah pulang } \\
\text { (aktivitas pribadi) }\end{array}$ & $\begin{array}{l}\text { corona virus Jakarta } \\
\text { salah kawan } \\
(\text { COVID-19) }\end{array}$ \\
\hline 4. & $\begin{array}{l}\text { gym berat angkat } \\
\text { anak ajak } \\
\text { (olahraga) }\end{array}$ & $\begin{array}{l}\text { bangun Jakarta mama } \\
\text { keluarga sambal } \\
\text { (keluarga) }\end{array}$ & $\begin{array}{l}\text { twitter banjir rumah } \\
\text { air doa } \\
\text { (bencana alam) }\end{array}$ & $\begin{array}{l}\text { corona psbb wabah } \\
\text { cegah lawan } \\
\text { (COVID-19) }\end{array}$ & $\begin{array}{l}\text { hujan pantai air } \\
\text { seru motor } \\
\text { (hobi) }\end{array}$ & $\begin{array}{l}\text { makan minum } \\
\text { bangun doa Allah } \\
\text { (aktivitas pribadi) }\end{array}$ \\
\hline 5. & $\begin{array}{l}\text { rumah sticker } \\
\text { iphone film korban } \\
\text { (hobi) }\end{array}$ & $\begin{array}{l}\text { instagram lari makan } \\
\text { twitter nonton } \\
\text { (hobi) }\end{array}$ & $\begin{array}{l}\text { baca malam shalat } \\
\text { keluarga nonton } \\
\text { (aktivitas pribadi) }\end{array}$ & $\begin{array}{l}\text { allah shalat puasa } \\
\text { ramadhan jumat } \\
\text { (keagamaan) }\end{array}$ & $\begin{array}{l}\text { teman bantuan } \\
\text { banjir bogor logistik } \\
\text { (bencana alam) }\end{array}$ & $\begin{array}{l}\text { sehat takut sakit } \\
\text { rezeki teman } \\
\text { (kesehatan) }\end{array}$ \\
\hline
\end{tabular}


Berdasarkan preferensi tersebut, maka hasil pemodelan dengan Agglomerative Clustering dipilih sebagai model yang merepresentasikan lima dominan topik yang dibahas oleh setiap pengguna aktif.

Perbandingan topik tweets pengguna aktif periode sebelum dan setelah COVID-19 dapat dilihat pada Tabel 7. Topik terkait COVID-19 menjadi topik dominan yang dibahas oleh pengguna twitter pada periode setelah COVID-19. Hal ini sejalan dengan maraknya pandemi COVID-19 pada waktu tersebut. Kemudian, pandemi COVID-19 dapat mempengaruhi topik postingan pada pengguna twitter. Hal ini terlihat pada akun pengguna (a)bintangnoru. Sebelum pandemi COVID-19 akun ini dominan melakukan topik tweet mengenai pekerjaan dan hobi. Namun semenjak pandemi COVID-19, akun ini dominan melakukan tweet mengenai dampak pandemi COVID-19 dan aktivitas di dalam rumah. Kemudian, akun@musniumar pada sebelum COVID-19 banyak melakukan tweet tentang aktivitas pribadi dan pekerjaan, namun semenjak pandemi COVID-19 akun ini banyak melakukan tweet mengenai dampak pandemi di masyarakat. Hal yang sama juga terjadi pada akun@rockerspantura. Dari hasil identifikasi ini diperoleh bahwa pandemi COVID-19 dapat mempengaruhi perubahan perilaku pengguna twitter dalam memilih topik tweet.

\section{B. Perbandingan jumlah tweet pada periode sebelum dan setelah COVID-19}

Proses identifikasi perbandingan jumlah tweet didasarkan pada ketiga akun pengguna yang aktif pada Tabel 4. Berdasarkan hasil akumulasi pada tweet pengguna tersebut, kenaikan jumlah tweet pada periode setelah COVID-19 terjadi pada rentang jam 1 dinihari sampai jam 5 sore. Persentase kenaikan tertinggi terjadi di jam 2 pagi sampai 7 pagi, kemudian pada jam 10 pagi sampai 12 siang.

Secara keseluruhan, rata-rata jumlah tweet perhari dan perjam selama pandemi COVID-19 mengalami mengalami kenaikan. Menariknya, pada jam kerja pada rentang pukul 7 pagi sampai 16 sore, terjadi kenaikan jumlah tweet sebesar 58\%. Hal ini mungkin dipengaruhi oleh aktivitas selama pandemi yang mengharuskan masyarakat menetap di rumah masing-masing. Kondisi ini menyebabkan selama pandemi COVID-19 pengguna twitter lebih aktif melakukan tweet pada pada jam kerja.

\section{Perbandingan popularitas pengguna twitter pada periode sebelum dan setelah COVID-19}

Perbandingan nilai follower rank pengguna aktif dapat dilihat pada Tabel 6. Pada periode sebelum COVID-19, keseluruhan pengguna aktif periode sebelum COVID-19 didominasi oleh akun dengan nilai follower diatas 5k. Bahkan akun@fahiraidris memiliki follower sebanyak 608k. Hal ini menunjukkan bahwa pengguna aktif periode sebelum COVID memiliki pengaruh yang cukup besar dalam jaringan interaksinya. Jika dilihat berdasarkan nilai follower, mereka merupakan pengguna yang sudah cukup populer di platform twitter, sedangkan pada periode setelah COVID-19, 60\% dari pengguna memiliki jumlah follower dibawah 5k. Bahkan akun @aryabima_16 hanya memiliki follower sebanyak 325 orang. Hal ini menunjukkan adanya perubahan peran pengguna aktif selama pandemi COVID-19.

Selanjutnya, periode setelah COVID-19 menunjukkan bahwa aktor utama dalam sebuah jaringan tidak hanya didominasi oleh akun dengan nilai follower rank tinggi tetapi juga didominasi oleh akun dengan nilai follower rank rendah. Dari identifikasi ini diperoleh bahwa pendemi COVID-19 mempengaruhi tipe pengguna twitter yang tidak populer menjadi lebih aktif melakukan tweet.

\section{KESIMPULAN}

Identifikasi terhadap perilaku pengguna twitter menggunakan analisis profil pengguna aktif menghasilkan tiga perubahan perilaku yang terjadi selama pandemi COVID-19. Pertama, perubahan pada topik postingan tweet. Pada periode sebelum COVID-19, dominan topik yang muncul berupa aktivitas pribadi, keluarga atau topik yang berhubungan dengan pekerjaan. Pada periode saat COVID-19, dominan topik yang muncul adalah mengenai COVID-19, hobi dan aktivitas di dalam rumah. Hal ini sejalan dengan situasi pandemi COVID-19 yang sedang meningkat pesat. Kedua, intensitas tweet pada periode setelah COVID-19 mengalami kenaikan 58\%. Kenaikan didominasi pada periode jam kerja antara pukul 7 pagi sampai dengan 4 sore. Hal ini dipengaruhi oleh aktivitas selama awal pandemi yang mengharuskan warga menetap di rumah. Ketiga, interaksi pengguna aktif selama masa pandemi tidak hanya didominasi oleh pengguna dengan nilai popularitas tinggi, tetapi juga pengguna dengan nilai popularitas rendah. Dalam kasus ini, $60 \%$ dari pengguna aktif periode setelah COVID-19 didominasi oleh pengguna dengan nilai follower dibawah 5k. Dari perubahan ketiga perubahan perilaku tersebut dapat diperoleh bahwa pandemi COVID-19 mempengaruhi perubahan perilaku pengguna dalam menggunakan sosial media twitter.

Dari penelitian ini terdapat tantangan utama yaitu alur informasi setiap topik dan pembahasan dari interaksi pengguna twitter sangat dinamis. Sehingga penelitian selanjutnya dapat melakukan eksplorasi penanganan masalah tersebut untuk mengetahui perubahan perilaku pengguna twitter.

\section{DAFTAR PUSTAKA}

ABD-ALRAZAQ, A., ALHUWAIL, D., HOUSEH, M., HAI, M., \& SHAH, Z. (2020). Top concerns of tweeters during the COVID-19 pandemic: A surveillance study. Journal of Medical Internet Research, 22(4), 1-9. https://doi.org/10.2196/19016

ABDELSADEK, Y., CHELGHOUM, K., 
HERRMANN, F., KACEM, I., \& OTJACQUES, B. (2018). Community extraction and visualization in social networks applied to Twitter. Information Sciences, 424, 204-223.

https://doi.org/10.1016/j.ins.2017.09.022

AHMED, M. S., AURPA, T. T., \& ANWAR, M. M. (2021). Detecting sentiment dynamics and clusters of Twitter users for trending topics in COVID-19 pandemic. PLOS ONE. https://doi.org/10.1371/journal.pone.0253300

AHMED, W., VIDAL-ALABALL, J., SEGUI, F. L., \& MORENO-SÁNCHEZ, P. A. (2020). A social network analysis of tweets related to masks during the covid-19 pandemic. International Journal of Environmental Research and Public Health, 17(21), 1-9. https://doi.org/10.3390/ijerph17218235

AL-SHARGABI, A. A., \& SELMI, A. (2021). Social Network Analysis and Visualization of Arabic Tweets during the COVID-19 Pandemic. IEEE. https://doi.org/10.1109/ACCESS.2021.3091537

BASIRI, M. E., NEMATI, S., ABDAR, M., ASADI, S., \& ACHARRYA, U. R. (2021). A novel fusion-based deep learning model for sentiment analysis of COVID-19 tweets. KnowledgeBased Systems, 228, 107242. https://doi.org/10.1016/j.knosys.2021.107242

COSTA, G., \& ORTALE, R. (2021). Jointly modeling and simultaneously discovering topics and clusters in text corpora using word vectors. Information Sciences, 563, 226-240. https://doi.org/10.1016/j.ins.2021.01.019

HAUPT, M. R., JINICH-DIAMANT, A., LI, J., NALI, M., \& MACKEY, T. K. (2021). Characterizing twitter user topics and communication network dynamics of the "Liberate" movement during COVID-19 using unsupervised machine learning and social network analysis. Online Social Networks and Media, 21(December 2020). https://doi.org/10.1016/j.osnem.2020.100114

HUNG, M., LAUREN, E., HON, E. S., BIRMINGHAM, W. C., XU, J., SU, S., ... LIPSKY, M. S. (2020). Social network analysis of COVID-19 sentiments: Application of artificial intelligence. Journal of Medical Internet Research, 22(8), 1-13. https://doi.org/10.2196/22590

LOSSIO-VENTURA, J. A., GONZALES, S., MORZAN, J., ALATRISTA-SALAS, H., HERNANDEZ-BOUSSARD, T., \& BIAN, J. (2021). Evaluation of clustering and topic modeling methods over health-related tweets and emails. Artificial Intelligence in Medicine, 117(March), 102096 https://doi.org/10.1016/j.artmed.2021.102096

MAILOA, E. (2020). Analisis Node dengan
Centrality dan Follower Rank pada Twitter. Jurnal RESTI (Rekayasa Sistem Dan Teknologi Informasi), 4(5), 937-942. https://doi.org/10.29207/resti.v4i5.2398

MARTIN, C., \& NIEMEYER, P. (2020). On the impact of network size and average degree on the robustness of centrality measures. Network Science, (2020), 1-22. https://doi.org/10.1017/nws.2020.37

MITTAL, D., SUTHAR, P., PATIL, M., PRANAYA, P. G. S., RANA, D. P., \& TIDKE, B. (2020). Social Network Influencer Rank Recommender Using Diverse Features from Topical Graph. Procedia Computer Science, 167(2019), 18611871.

https://doi.org/10.1016/j.procs.2020.03.205

PASCUAL-FERRÁ, P., ALPERSTEIN, N., \& BARNETT, D. J. (2020). Social Network Analysis of COVID-19 Public Discourse on Twitter: Implications for Risk Communication. Disaster Medicine and Public Health Preparedness, 1-9. https://doi.org/10.1017/dmp.2020.347

STOLZ, S., \& SCHLERETH, C. (2021). Predicting Tie Strength with Ego Network Structures. Journal of Interactive Marketing, 54, 40-52. https://doi.org/10.1016/j.intmar.2020.10.001

TOMASOA, L., IRIANI, A., \& SEMBIRING, I. (2019). Ekstraksi Knowledge tentang Penyebaran \#Ratnamiliksiapa pada Jejaring Sosial (Twitter) menggunakan Social Network Analysis (SNA). Jurnal Teknologi Informasi Dan Ilmu Komputer, 6(6), 677. https://doi.org/10.25126/jtiik.2019661710

VALDEZ, D., TEN THIJ, M., BATHINA, K., RUTTER, L. A., \& BOLLEN, J. (2020). Social media insights into US mental health during the COVID-19 pandemic: Longitudinal analysis of twitter data. Journal of Medical Internet Research, https://doi.org/10.2196/21418

YAO, Q., YI, R., LI, M., SONG, L., \& CRABBE, M. J. C. (2021). Safety knowledge sharing on Twitter: A social network analysis. Safety Science, 143(April), 105411. https://doi.org/10.1016/j.ssci.2021.105411

YIP, W. S., \& TO, S. (2021). Identification of stakeholder related barriers in sustainable manufacturing using Social Network Analysis. Sustainable Production and Consumption, 27, 1903-1917. https://doi.org/10.1016/j.spc.2021.04.018

ZHAO, G., LOU, P., QIAN, X., \& HOU, X. (2020). Personalized location recommendation by fusing sentimental and spatial context. Knowledge-Based Systems, 196, 105849. https://doi.org/10.1016/j.knosys.2020.105849 